\title{
THE EFFECTS OF 2008 GLOBAL ECONOMIC CRISIS ON BORROWING RATES OF MANUFACTURING COMPANIES: PRE-CRISIS AND CRISIS COMPARISON
}

\author{
Berna DÖMBEKCÍ
}

\begin{abstract}
The global economic crisis of 2008 has affected more or less every country. Governments have to take special precautions to ease the severe effects of the crisis in their financial and real sectors. The interest rate is an important indicator of economic stability and should be maintained at a level where the economic agents do not decide to postpone their growth plans. For this reason, this article will focus on the effects of the 2008 global economic crisis on the borrowing rates of Turkish manufacturing companies listed at the Bourse Istanbul (BIST) from a pre-crisis and crisis perspective. These effects are studied according to firm classifications based on age and cash holding behavior.
\end{abstract}

Keywords: crisis, manufacturing companies, borrowing rates, cash holding

Jel Codes: G32, G01, E58

\section{KÜRESEL EKONOMİK KRIZİNIN İMALAT FIRMALARI BORÇLANMA ORANLARINA ETKILERİ: KRİZ-ÖNCESİ VE KRİZ DÖNEMLERININ KARŞILAŞTIRMASI}

\section{Öz}

2008 global krizi az veya çok birçok ülkeyi etkilemiştir. Hükümetler, finans ve reel sektörlerinde meydana gelebilecek krizin acı etkilerine karşı özel önlemler almak durumunda kalmışlardır. Faiz oranı ekonomik istikrarın önemli bir göstergesidir ve ekonomik birimlerin büyüme

Öğr. Gör. Dr. Kırklareli Üniversitesi, Sosyal Bilimler Meslek Yüksekokulu, dombekci@yahoo.com 
planlarını ertelememesi için belli bir seviyede tutulması gerekmektedir. Bu sebeple bu makale, 2008 ekonomik krizinin Borsa İstanbul’a kote olan üretim firmalarının borçlanma oranlarına olan etkileri üzerine kriz öncesi ve kriz dönemi yaklaşımı ile eğilecektir. Bu etkiler firmaların yaşı ve nakit tutma oranları bazında yapılan sinıflandırmaya göre incelenecektir.

Anahtar Kelimeler: Kriz, üretim firmaları, borçlanma oranları, nakit tutma Jel Kodları: G32, G01, E58

\section{Introduction}

The global economic crisis initiated by subprime mortgage crisis in United States of America (USA) in August 2007 that spread out all over the world in 2008, is no doubt one of the most important economic events that the world has gone through. Its effects are compared to Great Depression of the 1930s. World trade volume in goods and services which increased by $2,9 \%$ in 2008 recorded a significant contraction of 10,5\% in 2009 (IMF, 2012). This contraction is the largest decrease since World War II.

Central Banks injected huge amounts of liquidity to money markets and governments in the USA and Euro area seized many banks. The investment banking model has ended. Big banks and financial institutions announced big losses. Central Banks decreased policy interest rates to avoid credit crunch in the markets and governments announced special rescue packages to restore confidence in their economies. Many countries had to face gross domestic product (GDP) contractions either in 2009 and/or in 2010 as a consequence of world trade decrease. This contraction has been felt much more on advanced economies than emerging and developing countries. The USA recorded consecutive GDP contractions in years 2008 and 2009 as the origin country of the crisis. Being in the second group of least affected countries, Turkey is also affected because more than $50 \%$ of its foreign trade volume is with European Union (EU).

The aim of this article is to find out the effects of the 2008 global economic crisis on the borrowing rates of Turkish manufacturing companies listed at the Bourse Istanbul (BIST). The analysis will show the differences in effects between firms classified based on age and cash holding behavior.

\section{Literature Review}

In line with the aim of the article, many articles related to crisis are revised. Gambacorta (2004) investigates how the Italian banks set the interest rates. After conducting a panel data analysis with macro and bank-specific variables for immediate pass-through, pass-through after a quarter and long-run elasticity, the findings reveal that differences in the banking rates pass-through exist only in the short term. The empirical analysis shows that a $1 \%$ increase in the monetary policy indicator raises interest rate on short-term lending immediately by around 
$0,5 \%$ and $0,9 \%$ after a quarter. In the long run, banking rates are in line with the money market rates. In addition, short-term lending rates of financially sound banks show less reaction to a monetary policy shock. When the ratio of long-term loans is higher, banks prefer less to change their lending rates. The liability structure of the banks play crucial role and the size of the banks is not found relevant.

Many studies are conducted on cash holding strategy of firms before and after crisis. One of them is the article written by Arslan, Florackis and Ozkan (2006) who analyze impact of cash reserves in corporate investment. This analysis is performed with firm-level data in pre-crisis (1998-2000) and crisis period (2001-2002) for Turkey by setting cash holding quartiles. They state that cash holdings seem to be a cushion against cash flow fluctuations. Particularly, it gains more importance for financially constrained firms and during a crisis period. The empirical results provide evidence that firms with more growth opportunities tend to save more not to bypass valuable investment projects when cash flows are decreased and external finance becomes costly. Small firms need more cash reserves as they are more subject to information asymmetry problems. Firms hold more cash as their cash flow increases and low and intermediate level of short-term debt behave like a substitute of cash holdings. At the high level, cushioning role of cash takes its place on the stage to minimize risk of financial distress. In summary, investments of financially constrained firms are more sensitive to cash reserves.

Campello, Graham and Harvey (2009) conducted a survey among 1.050 chief financial officers (CFOs) in 39 countries in North America, Europe and Asia to see real effects of financial constraints during 2008 global crisis. The survey provides evidence that financially constrained firms prefer to hold more cash to be able to use it in difficult times. Most of these firms reject to undertake profitable investments due to external finance difficulties and even some firms plan to sell their assets for cash during crisis. They also plan to decrease their technology, marketing and employment expenditures. Financially constrained firms substantially burn out their cash holdings and plan to cease dividend payments. However, unconstrained firms' indicators stay constant; in other words, stay as they were before crisis. These results are valid in all the three continents.

Campello, Giambona, Graham and Harvey (2010) conducted a survey to 800 CFOs from North America, Europe, and Asia to analyze the crisis effects. The aim is to understand CFOs' preferences on different sources of liquidity like credits, cash holdings and profits and the relation between liquidity management and company expenditure plans like investment, technology, and employment expenditures during a crisis period. The results of the survey indicate that firms that own more cash holdings and have more cash flows tend to use fewer credits thus firms with sufficient internal funds choose not to use external funds during a crisis. The reason for this is the increased credit costs. When firm profitability thus its cash flow increases, the capacity of firm to raise more credits also increases. Meanwhile, if firms with higher cash flows prefer to hold more cash in their pockets, they tend to use less credits during difficult times. Thus cash flows and cash holdings of a firm have opposing effects on the use of credits. At the average level of cash, an increase in credits does not change a firm's investment plans. In contrast; investment, technology and employment expenditures are decreased when a firm lacks credits. At the higher 
level of cash, raising more credits increases investment plans of a firm. At this level, availability of credits diminishes the negative effects of crisis on real-side decisions, such as capital investment, technology spending and employment.

Campello, Giambona, Graham, and Harvey (2010) investigate this time the behavior of firms corresponding to internal and external finance resources after 2008 global economic crisis. They survey 397 US firms' CFOs. Firms become more conservative and prefer to use their internal cash flows instead of using from their credit capacity. This evidence is in line with the findings of Santos (2011) whose article finds that credits become more costly and harder to obtain. In line with this view, short and long-term bank credits lending rates data are collected to analyze in detail the effects of the crisis on Turkish corporate sector.

Duchin, Ozbas and Sensoy (2010) also examine the effects of internal and external finance availability on investment with firm-level data for the period July 1, 2006-June 30, 2008. Their base regression takes investment before and after crisis as dependent variable and cash holdings, net debt, external financing constraints and dependence on external finance as independent variables. The results underline that post-crisis investment of financially constrained firms declined significantly thus is higher the impact of internal resources (previous year) for this type of firms. The post-crisis decline in investment is particularly severe for firms in industries that are historically more dependent on external finance or external equity finance (Rajan and Zingales, 1998). These firms' post-crisis investment was also been strongly affected by their cash reserves. Meanwhile, net short-term debt has a negative relationship with post-crisis changes in investment contrary to long-term debt. They grouped firms into high-cash (top quintile) and low-cash (bottom quintile) portfolios based on their cash balances. With the precautionary savings role, high-cash firms recorded abnormal returns in their stock prices compared to low-cash firms by the end of 2007. It is seen that financial liquidity increases value of investment during the crisis.

Çavuşoğlu (2010) analyzed the impact of policy interest rate changes to the banking interest rates for the periods of 2001-2009 and 2004-2009 in Turkey. Interest rate pass-through has been found fast and high in the long run but not in the short run. The findings also reveal that the impact is higher for lending interest rates compared to banking deposit rates however with more lags when the policy rate is decreased. The effect is more pronounced for consumer loans compared to corporate loans because small and medium enterprises (SMEs) are heavily dependent on bank financing. Thus banks are reluctant to decrease their lending rates in the short run although the policy rate is decreased. The analysis gives an average lag of three months for affecting the banking lending rates when the central bank changes the policy rate.

Hansen and Welz (2011) concentrated on the interest rate pass-through in Sweden before and during the global crisis. Lending rates and deposit rates (retail rates) increase in line with policy rate until autumn 2008 but they go downward following the decrease in policy rate. Until 2007, the increase in money market rates is higher than the increase in short run lending rates. In addition, it is seen that long run interest rate does not closely follow long-term money market rates as before. During the global crisis, interest rate spreads begin to increase and do not return to pre-crisis levels after. The impact of the policy rate on retail rates weakens. In 2009, markets conditions are improved thus lending rates are declined. Finally, they underline that the reduc- 
tion in policy rate is well reflected to the short-term rates during the economic crisis however the channel is impaired for long-term lending rates due to the liquidity crunch globally. As the credit crunch is softened in 2009, long-term lending rates become parallel with the policy rate.

\section{Crisis Effects on Turkish Corporate Loans}

The effects of the global economic crisis can be seen on the quarterly growth of corporate loans by the Turkish banking sector. The corporate loans are divided into two subgroups as cash basis loans and non-cash basis loans as shown in Table: 1. In March 2009, the smallest quarterly growth $(1,9 \%)$ in total corporate loans is recorded since September 2006. In June 2009, the first contraction $(-1,6 \%)$ in total corporate loans is detected as seen in Table: 2 . The value of the total corporate loans used by corporations melts down by seven billion TL in one quarter which is a sign of economic slowdown. The recovery begins in September 2009 and the sustainable growth in corporate loans is achieved then afterwards. Contrary to Santos findings in his article, the special precautions taken by Turkish government attenuated in a sense the effects of the global economic crisis on the real sector.

Table 1. Total Corporate Loans (Billion TL)

\begin{tabular}{|l|r|r|r|}
\hline Periods & \multicolumn{1}{|c|}{$\begin{array}{c}\text { Cash basis } \\
\text { loans }\end{array}$} & $\begin{array}{c}\text { Non-cash basis } \\
\text { loans }\end{array}$ & $\begin{array}{c}\text { TOTAL } \\
\text { CORPORATE LOANS }\end{array}$ \\
\hline Jun-06 & 134 & 78 & 212 \\
\hline Sep-06 & 136 & 87 & 222 \\
\hline Dec-06 & 153 & 87 & 252 \\
\hline Mar-07 & 164 & 88 & 261 \\
\hline Jun-07 & 171 & 91 & 272 \\
\hline Sep-07 & 179 & 93 & 301 \\
\hline Dec-07 & 204 & 97 & 338 \\
\hline Mar-08 & 226 & 112 & 361 \\
\hline Jun-08 & 242 & 120 & 374 \\
\hline Sep-08 & 254 & 120 & 392 \\
\hline Dec-08 & 266 & 126 & 400 \\
\hline Mar-09 & 269 & 131 & 393 \\
\hline Jun-09 & 264 & 129 & 399 \\
\hline Sep-09 & 269 & 130 & 414 \\
\hline Dec-09 & 280 & 134 & 420 \\
\hline Mar-10 & 279 & 141 & 454 \\
\hline Jun-10 & 306 & 148 & 469 \\
\hline Sep-10 & 316 & 153 & 515 \\
\hline Dec-10 & 352 & 164 & 553 \\
\hline Mar-11 & 377 & 176 & 605 \\
\hline Jun-11 & 413 & 193 & 650 \\
\hline Sep-11 & 443 & 207 & \\
\hline
\end{tabular}

Source: BRSA*, Financial Markets Report, June 2006-September 2011, pages 21-22

${ }^{\star}$ BRSA (Banking Regulation and Supervision Agency) 
Table 2. Growth of Total Corporate Loans (\%)

\begin{tabular}{|l|r|r|r|}
\hline Periods & \multicolumn{1}{|c|}{$\begin{array}{c}\text { Cash basis } \\
\text { loans }\end{array}$} & $\begin{array}{c}\text { Non-cash basis } \\
\text { loans }\end{array}$ & $\begin{array}{c}\text { TOTAL } \\
\text { CORPORATE LOANS }\end{array}$ \\
\hline Jun-06 & 1,4 & 11,1 & 5,0 \\
\hline Sep-06 & 13,0 & 0,2 & 8,0 \\
\hline Dec-06 & 7,0 & 1,6 & 5,0 \\
\hline Mar-07 & 4,2 & 2,8 & 3,7 \\
\hline Jun-07 & 4,7 & 2,7 & 4,0 \\
\hline Sep-07 & 14,1 & 4,0 & 10,6 \\
\hline Dec-07 & 10,9 & 15,8 & 12,5 \\
\hline Mar-08 & 6,9 & 6,8 & 6,8 \\
\hline Jun-08 & 5,1 & 0,4 & 3,6 \\
\hline Sep-08 & 4,8 & 4,7 & 4,8 \\
\hline Dec-08 & 1,0 & 3,9 & 1,9 \\
\hline Mar-09 & $-1,7$ & $-1,3$ & $-1,6$ \\
\hline Jun-09 & 1,9 & 0,5 & 1,4 \\
\hline Sep-09 & 4,0 & 3,3 & 3,8 \\
\hline Dec-09 & $-0,4$ & 5,1 & 1,4 \\
\hline Mar-10 & 9,5 & 5,1 & 8,0 \\
\hline Jun-10 & 3,4 & 3,5 & 3,4 \\
\hline Sep-10 & 11,3 & 6,8 & 9,8 \\
\hline Dec-10 & 7,3 & 7,3 & 7,3 \\
\hline Mar-11 & 9,3 & 9,6 & 9,4 \\
\hline Jun-11 & 7,5 & 7,5 & 7,5 \\
\hline Sep-11 & & & \\
\hline & & & \\
\hline
\end{tabular}

Source: BRSA, Financial Markets Report, June 2006-September 2011, pages 21-22

\section{Empirical Research}

In light of the foreign literature, an empirical analysis is conducted for Turkish manufacturing firms to see the real effects of the global crisis on their borrowing rates.

\section{I. Data and Sample Selection}

In this study, the quarterly annual reports of 118 manufacturing firms are revised to collect their short-term and long-term fixed borrowing rates in TL, USD and EURO between 2006Q1 and 2011Q3. Thus 2.714 observations are obtained. The firms show these borrowing rates within an interval defined by minimum and maximum values from which average values are calculated. For other listed manufacturing firms, interest rates are not disclosed in their annual reports for much of the study period. The quarterly financial statements' data are obtained via FINNET. These financial statements are prepared according to International Financial Reporting Standards (IFRS). 


\subsection{Determination of Pre-Crisis and Crisis Periods}

When the search of an official announcement by CBRT is conducted to find out a date for the start of the crisis for Turkish economy, the results focus on some points: the CBTR (Central Bank of Turkish Republic) announced that they decided to make their first overnight borrowing rate cut in November 19, 2008 to attenuate the slowing of economic activities (Başçı, 2008). This can be assumed as the official beginning of the global crisis in Turkey. The FED made its first rate cut in August 2007 to avoid credit crunch risk in the USA where this month is used by many researchers as the beginning of crisis. Furthermore, in almost all the reports of CBRT, the beginning of the global crisis in the world is accepted as August 2007 (CBRT, 2008).

For Turkey, the crisis effects will be easily discovered when the data is divided into two subgroups: pre-crisis period (2006Q1-2008Q3) and crisis period (2008Q4-2011Q3). This division is made according to the results of Financial Stress Index (FSI) of Turkey (IMF), of Financial Pressure Index (FPI) (Dömbekci, 2012) and the macroeconomic parameters like industrial production index, capacity usage (beginning of contraction in September 2008), employment rate, CBRT first overnight borrowing rate cut in November 2008 and GDP contraction (first contraction of 7\% in 2008Q4).

\subsection{Crisis Effects on Borrowing Rates}

The financing cost is an important aspect of running business for the firms especially for the emerging market economies where the firms lack adequate equity to finance their investments and the financial system is heavily dependent on banks. For this reason, the price of corporate loans is of crucial value and should be examined carefully. With the global financial crisis, the interest rates of banking loans are significantly affected in Turkey and the government is obliged to take some precautions to avoid a possible credit crunch via monetary policies.

The descriptive analyses of the minimum and maximum fixed borrowing rates of listed firms for each currency type according to their maturity for twenty three quarters are provided in Table 3. 
Table 3. Descriptive Statistics of Borrowing Rates (2006Q1-2011Q3)

\begin{tabular}{|l|ccccc|}
\hline Variable & Obs & Mean & Std. Dev. & Min & Max \\
\hline STTLMIN & 1467 & 13,25 & 5,82 & 0,00 & 34,00 \\
STTLMAX & 1467 & 15,39 & 6,57 & 0,11 & 59,40 \\
& & & & & \\
STUSDMIN & 1194 & 4,93 & 2,01 & 0,48 & 15,00 \\
STUSDMAX & 1194 & 6,00 & 2,49 & 0,05 & 18,00 \\
& & & & & \\
STEUROMIN & 1327 & 4,97 & 2,14 & 0,00 & 15,25 \\
STEUROMAX & 1327 & 5,79 & 2,43 & 1,07 & 15,25 \\
& & & & & \\
LTTLMIN & 374 & 13,37 & 4,70 & 0,84 & 30,00 \\
LTTLMAX & 374 & 14,84 & 5,67 & 0,84 & 30,00 \\
& & & & & \\
LTUSDMIN & 780 & 5,13 & 2,01 & 0,49 & 12,00 \\
LTUSDMAX & 789 & 5,73 & 2,20 & 0,10 & 12,00 \\
& & & & & \\
LTEUROMIN & 919 & 5,16 & 2,19 & 0,06 & 14,00 \\
LTUROMAX & 910 & 5,69 & 2,20 & 0,09 & 14,00 \\
\hline
\end{tabular}

Source: Annual reports of BIST firms

The descriptive analyses in Table: 4 reveal that there is approximately $4 \%$ decrease in average short-term TL borrowing rate when we compare the pre-crisis and crisis period rates. This decrease is more underlined as it approaches to 5\%-6\% in the case of long-term TL borrowing rates. For the bank lending in USD, the firms' advantage is between 1,10\% and 1,50\% in shortterm and 1,90\% in long-term. The least interest rate advantage is on the EURO basis because the interest rates decrease by $0,40 \%$ in the short-term and $0,90 \%$ in the long-term respectively in the crisis period.

Table 4. Descriptive Statistics of Borrowing Rates (Pre-crisis \& Crisis)

\begin{tabular}{|l|ccccc|ccccc|}
\hline & \multicolumn{7}{|c|}{ PRE-CRISIS } & \multicolumn{5}{c|}{ CRISIS } \\
\hline Variable & Obs & Mean & Std. Dev. & Min & Max & Obs & Mean & Std. Dev. & Min & Max \\
\hline STTLMIN & 630 & 15,54 & 5,27 & 0,00 & 34,00 & 837 & 11,52 & $\mathbf{5 , 6 2}$ & 0,00 & 34,00 \\
STTLMAX & 630 & 18,11 & 5,08 & 2,10 & 59,40 & 837 & 13,34 & $\mathbf{6 , 8 2}$ & 0,11 & 59,40 \\
& & & & & & & & & & \\
STUSDMIN & 511 & 5,77 & 1,57 & 1,00 & 10,79 & 683 & 4,30 & $\mathbf{2 , 0 6}$ & 0,48 & 15,00 \\
STUSDMAX & 511 & 6,65 & 1,61 & 2,62 & 12,00 & 683 & 5,51 & $\mathbf{2 , 8 8}$ & 0,05 & 18,00 \\
& & & & & & & & & & \\
STEUROMIN & 613 & 5,12 & 1,60 & 0,00 & 13,00 & 714 & 4,83 & $\mathbf{2 , 5 0}$ & 0,00 & 15,25 \\
STEUROMAX & 613 & 6,02 & 1,89 & 2,58 & 15,00 & 714 & 5,60 & $\mathbf{2 , 8 0}$ & 1,07 & 15,25 \\
& & & & & & & & & & \\
LTTLMIN & 94 & 17,16 & 4,00 & 5,29 & 28,75 & 280 & 12,09 & $\mathbf{4 , 2 1}$ & 0,84 & 30,00 \\
LTTLMAX & 94 & 19,75 & 4,82 & 7,50 & 30,00 & 280 & 13,19 & $\mathbf{4 , 9 4}$ & 0,84 & 30,00 \\
LTUSDMIN & 340 & 6,15 & 1,39 & 3,00 & 12,00 & 440 & 4,34 & $\mathbf{2 , 0 6}$ & 0,49 & 12,00 \\
LTUSDMAX & 341 & 6,79 & 1,52 & 3,40 & 12,00 & 448 & 4,92 & $\mathbf{2 , 2 9}$ & 0,10 & 12,00 \\
LTEUROMIN & 431 & 5,49 & 1,81 & 1,83 & 12,00 & 488 & 4,87 & $\mathbf{2 , 4 4}$ & 0,06 & 14,00 \\
LTUROMAX & 430 & 6,16 & 1,75 & 1,82 & 13,40 & 480 & 5,27 & $\mathbf{2 , 4 6}$ & 0,09 & 14,00 \\
\hline
\end{tabular}

Source: Annual reports of BIST firms 


\subsection{Crisis Effects on Borrowing Rates in TL}

The mean short-term TL borrowing rate that is between $17 \%$ and $18 \%$ in the pre-crisis period jumps suddenly to around 20\% in 2008Q4. From this peak, it begins to reduce until $9 \%$ in 2010Q3 with the policy rate cuts by CBTR. Between 2010Q3 and 2011Q3, corporate loans' interest rates fluctuate between $9 \%$ and $10 \%$.

In the case of long-term TL credits, the average long-term borrowing rate fluctuates around $18 \%-20 \%$ until 2009 Q 1 then after it begins to decrease to $11 \%$ in 2010 Q 2 at which rate it stabilizes.

In the aftermath of the crisis, the tools used for financial markets stability and low interest rates by the FED had important implications for the recovery. One of the tools is the reduction of federal funds rate (short-term policy rate) that helps to lower long-term interest rates thus to stimulate the economy. The FED decreases this rate basically to $0 \%$ in December 2008 from $5,25 \%$ in September 2007. Thus, there is no place for further step. The other tool used is the large scale asset purchases (LSAPs) announced in March 2009 and November 2010. These assets are the government sponsored securities and the FED does not pay any money to purchase them instead they accept as reserve capital of the financial institutions that have sold them. These purchases increase the FED's balance sheet asset side by more than 2 trillion dollars. Consequently, 30 -year mortgage interest rate falls below $4 \%$ and corporate credit become available in the market (Bernanke, 2012).

Like many developed and emerging countries, Turkey has also used the policy rate tool to avoid credit crunch in the market. As shown in the Figure 1, Turkey makes the biggest policy rate cut in total between October 2008 and December 2009. The decisions of policy rate reduction can be seen in the Figure 2. In line with these interventions, the lending rates for commercial and corporate loans begin to decrease in the market. 


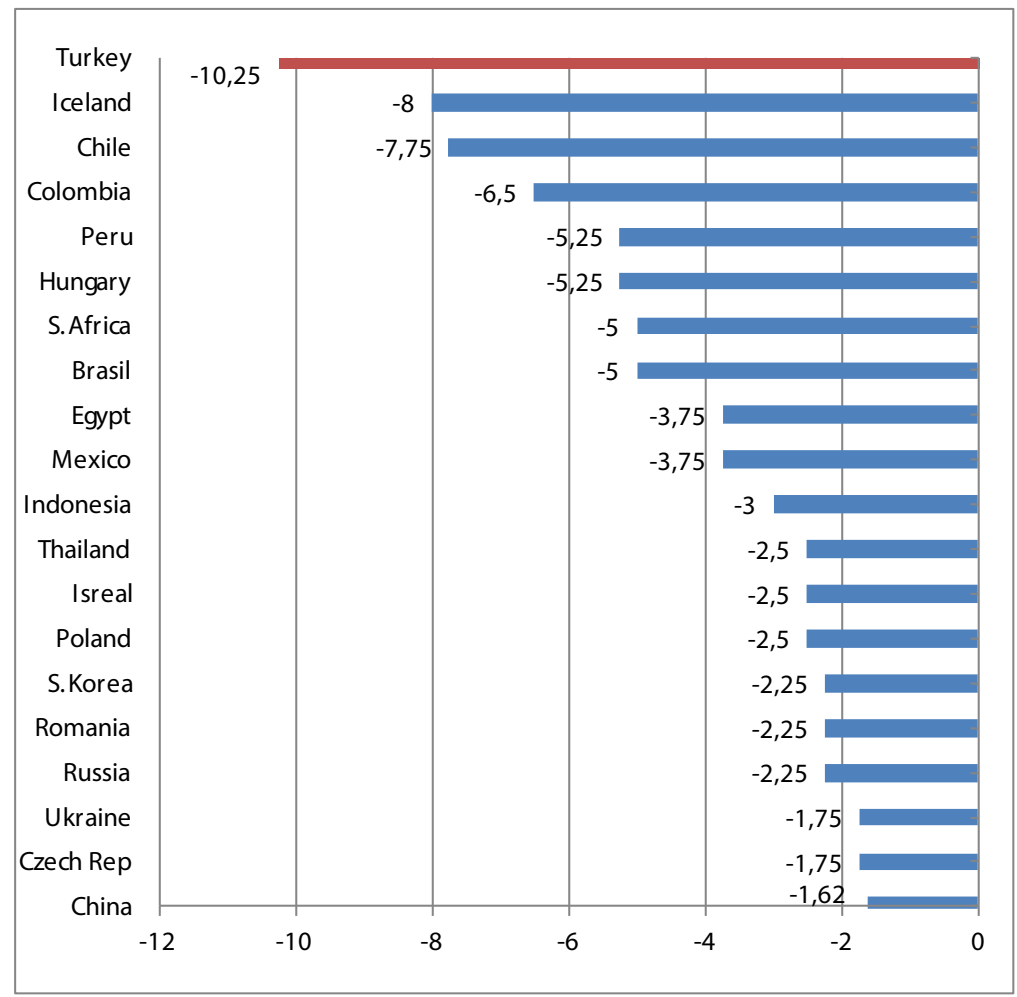

Figure 1. Change in Policy Rates of Emerging Market Economies

(Oct 2008 to Dec 2009, percentage points)

Source: Turhan (2010)

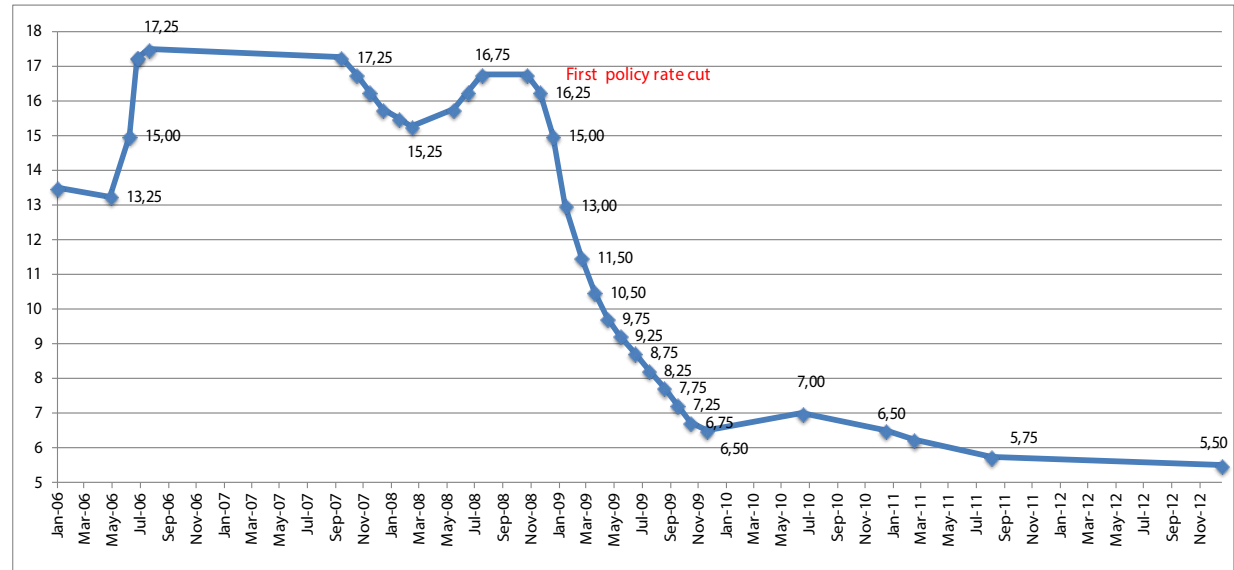

Figure 2. Change in Policy Rates of CBRT (\%)

Source: CBRT 
The data collected for the study gives the reflection of these decisions in the firms' financial statements. When CBRT policy rate and mean short-term TL borrowing rate of manufacturing firms are compared as seen in Figure 3, it is discovered that the average quarterly spread between short-term average borrowing rate in TL and policy rate is 0,65 percentage points in 2006, 1,41 in 2007 and 1,28 for the first three quarters of 2008 respectively. In the last quarter of 2008, this spread jumps to 5,31. It is realized as 5,87 for 2009 then starts to decrease in the following quarters. The average quarterly spread is recorded 3,13 for 2010 and 3,41 for the first three quarters of 2011 respectively. The spread increases in every quarter of 2011 to reach 4,23 percentage points in 2011Q3. The findings reveal that the spread decreases in 2010 and 2011 but does not return to pre-crisis levels.

The banks increase their short-term lending rates in 2008Q4 as a first response to financial crisis in Turkey although the CBRT begins its policy rate cuts to ease the economy at the same time. The average short-term lending rate begins to decrease in 2009Q1. Banks behave reluctantly to reduce their TL lending rates as much as the CBRT decreases its policy rates thus the spread enlarges in the crisis period.

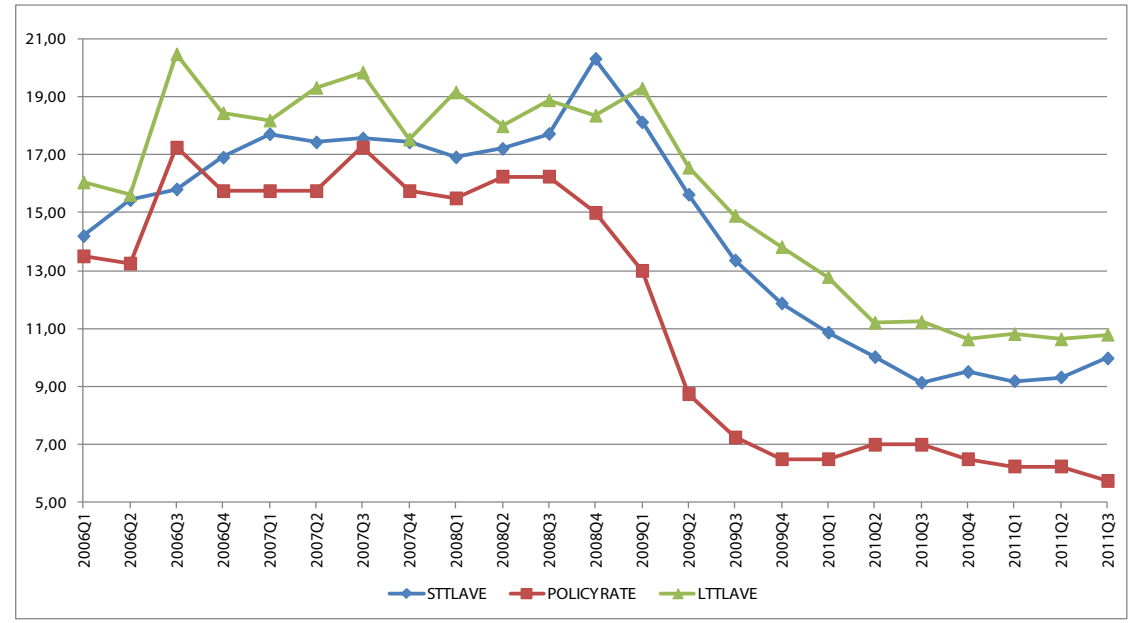

Figure 3. Short Term and Long Term Average Borrowing Rates in TL vs. Policy Rate

Source: Annual reports of BIST firms and CBRT

When the spread is calculated between policy rate and average long-term TL borrowing rate for each year, it is clear that the difference is more pronounced. The average quarterly spread is recorded 2,71 percentage points for 2006; 2,59 for 2007; 2,85 for 2008; 7,27 for 2009; 4,71 for 2010 and 4,67 for 2011 respectively. A high jump in the spread is realized in 2009Q1 for the long term borrowing rate whereas this jump can be seen in 2008Q4 for the short term borrowing rate. 
The average long-term TL borrowing rate makes its first significant reduction in 2009Q2 thus a lag of three months exists after the first reduction in the average short-term borrowing rate.

As mentioned before, the first policy rate cut is recorded in November 2008. The effect of this rate cut is reflected to short-term lending rates with a lag of three months. However, this lag extends to six months in the case of long-term lending rates for the manufacturing firms of the study.

\subsubsection{Crisis Effects on Borrowing Rates in USD}

The Figure 4 shows the development of average short-term and long-term borrowing rates for USD during the study period.

For USD credits, the mean short-term borrowing rate that is between 5,78\% and 6,62\% until 2007Q4, begins to drop from 6,62\% to 5,32\% in 2008Q2 and jumps suddenly to 6,43\% in 2008Q4. The rate seems to stabilize at this point until 2009Q3. From this peak, it begins to reduce until 4\% in 2010Q2 at which rate it stabilizes around. In the case of long-term credits, the mean long-term borrowing rate that is between 6,5\% and 7\% until 2007Q4, begins its gradual decrease until 2010Q4 where it stabilizes at around 4\%.

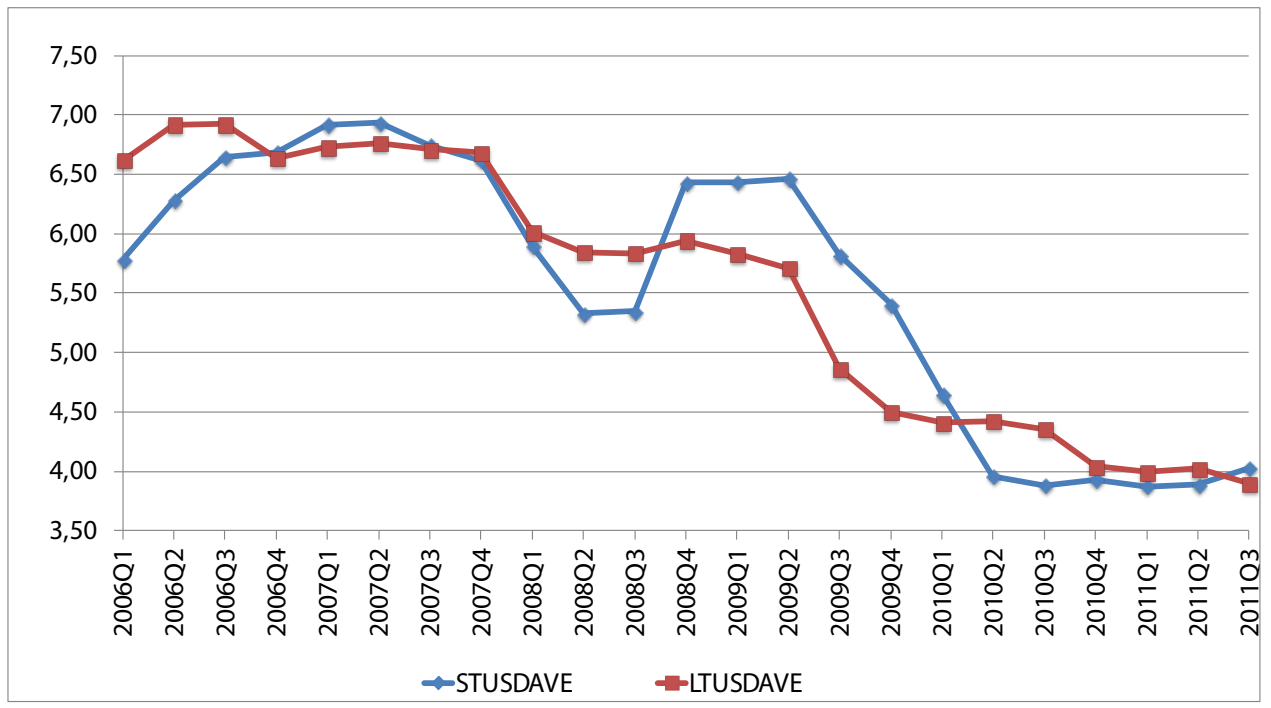

Figure 4. Short and Long Term Average Borrowing Rates - USD

Source: Annual reports of BIST firms 


\subsubsection{Crisis Effects on Borrowing Rates in EURO}

The Figure 5 shows the development of average short-term and long-term borrowing rates for EURO during the study period.

For EURO credits, the average short and long-term borrowing rates do not show much difference in their values and they tend to move together. The mean short-term borrowing rate steadily increases from $4,70 \%$ to reach its peak level 7,22\% in 2008Q4. After this peak level, it begins to decrease to reach 4,46\% in 2010Q4. Between 2010Q4 and 2011Q3, it fluctuates around $4 \%$ and $4,65 \%$. In the case of long-term credits, the mean long-term borrowing rate that is between 5\% and 6,81\% until 2008Q4, begins its gradual decrease to 4,85\% until 2009Q4 from where it stabilizes at around 4,5\% and 5\% until 2011Q3.

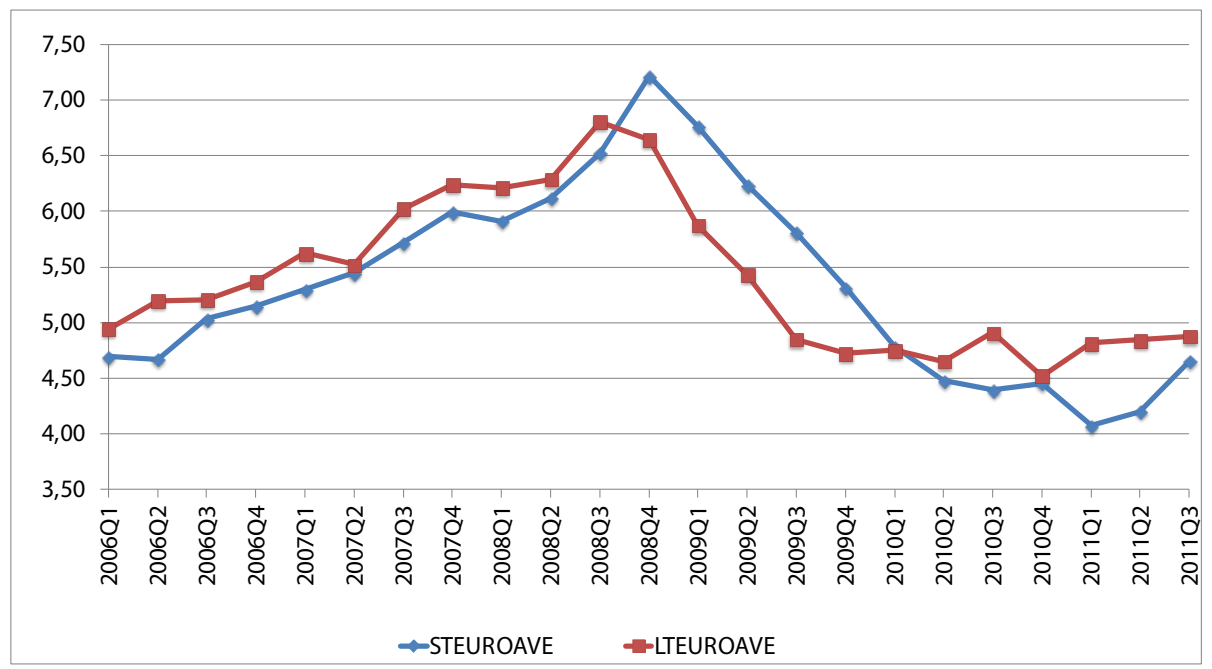

Figure 5. Short and Long Term Average Borrowing Rates - EURO

Source: Annual reports of BIST firms

\subsubsection{Firm Age and Borrowing Rates}

The pre-crisis and crisis difference in borrowing rates also differ slightly according to firm age. As mentioned before, the firms whose age is above 34 years, the median age of all firms in the analysis, are assumed to be old firms and vice versa. The Table 5 summarizes the differences in average borrowing rates between old and young firms in both pre-crisis and crisis periods. It is seen that these differences in short-term rates between old and young firms are magnified in the crisis period. From the short-term perspective, young firms have to bear higher borrowing rates in both periods except for Euro credits in the crisis period. This exception also counts for longterm EURO credits for both periods and long-term TL credits in the crisis period. 
Table 5. Average Borrowing Rates of Old vs. Young Firms

\begin{tabular}{|l|c|c|c|c|}
\hline ST & \multicolumn{2}{|c|}{ PRE-CRISIS } & \multicolumn{2}{c|}{ CRISIS } \\
\hline Variable & OLD & YOUNG & OLD & YOUNG \\
\hline STTLAVE & 16,6 & 17,1 & 11,8 & 13,0 \\
\hline STUSDAVE & 6,1 & 6,3 & 4,7 & 5,1 \\
\hline STEUROAVE & 5,4 & 5,7 & 5,4 & 5,1 \\
\hline LT & \multicolumn{2}{|c|}{ PRE-CRISIS } & \multicolumn{2}{c|}{ CRISIS } \\
\hline Variable & OLD & YOUNG & OLD & YOUNG \\
\hline LTTLAVE & 18,0 & 18,9 & 12,9 & 12,4 \\
\hline LTUSDAVE & 6,4 & 6,5 & 4,5 & 4,9 \\
\hline LTEUROAVE & 5,8 & 5,8 & 5,1 & 4,9 \\
\hline
\end{tabular}

Source: Annual reports of BIST firms

The Figure 6 and Figure 7 reveal the difference in borrowing costs for each currency type for the two sub-periods. In the short-term, the borrowing rates decrease is higher for old firms in TL and in USD loans whereas young firms benefit more from rate decreases in the case of Euro loans bearing in mind that the difference between two periods is already underlined being too small for the euro loans. In the long-term, the borrowing rates decrease is higher for young firms in TL and in Euro loans whereas old firms benefit more from rate decreases in the case of USD loans in the crisis period.

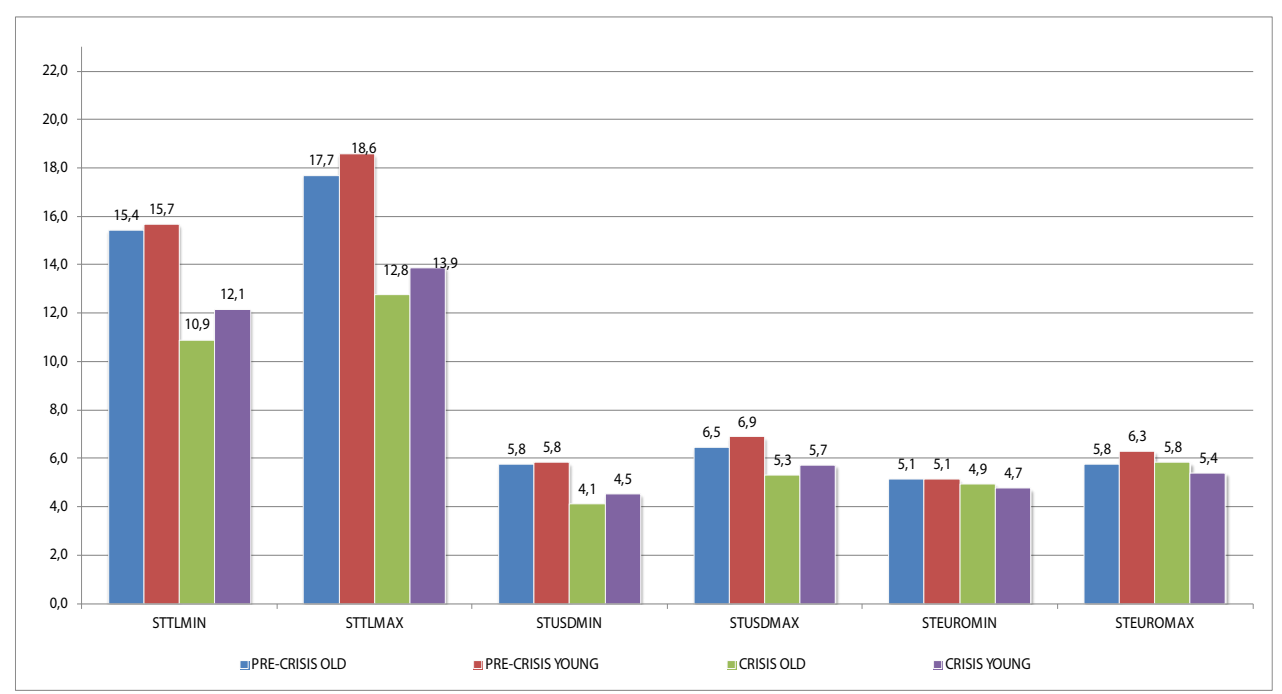

Figure 6. Short-term Borrowing Rates (Pre-Crisis and Crisis)

Source: Annual reports of BIST firms 


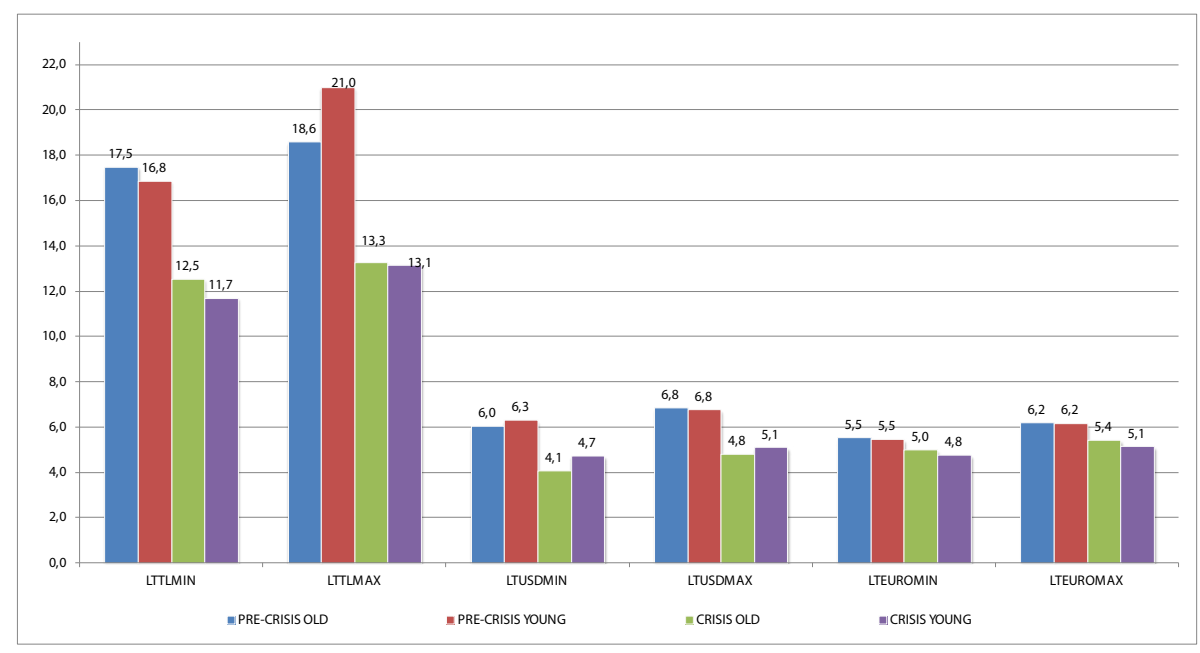

Figure 7. Long-term Borrowing Rates (Pre-Crisis and Crisis)

Source: Annual reports of BIST firms

\subsubsection{Cash Holding Behavior and Borrowing Rates}

As the literature mentioned in the previous chapters summarizes the importance of leverage and cash holdings for firms, it is beneficial to classify firms on the basis of their cash holding during the pre-crisis period. It is then examined whether firms that succeed to obtain a certain financial flexibility in the pre-crisis period benefit from it by having better financial profitability in the crisis period. First, the median value of ratios of cash holdings over total assets is calculated. The firms with ratios above the median value are assumed to be high cash (HC) firms and below it as low cash (LC) firms respectively.

When the borrowing rates of $\mathrm{HC}$ and LC firms are examined in the crisis period as shown in Table 6, the results provide evidence that firms that are used to have higher cash savings in their hands in the pre-crisis period have the opportunity to obtain short and long-term credits with lower interest rates in the crisis period compared to LC firms except for long-term TL credits. The reason for this exception is that LC firms need more external resources in the crisis period when the TL lending rates are decreased significantly in the market. The finding with HC firms is not surprising as the banks feel more comfortable to give credits to firms that own high cash reserves on their balance sheets thinking of them as liquid collaterals in a sense. 
Table 6. Average Borrowing Rates of HC and LC Firms in Crisis

\begin{tabular}{|l|c|c|}
\hline & \multicolumn{2}{|c|}{ CRISIS } \\
\hline \multirow{2}{*}{ STTLAVE } & HC & LC \\
\cline { 2 - 3 } STUSDAVE & 11,76 & 13,01 \\
STEUROAVE & 4,56 & 5,21 \\
LTTLAVE & 5,15 & 5,28 \\
LTUSDAVE & 13,30 & 12,03 \\
LTEUROAVE & 4,20 & 5,00 \\
\hline
\end{tabular}

Source: Annual reports of BIST firms

\section{Conclusion}

The global economic crisis that started in 2007 in the USA has severe effects on the developed and emerging economies. Governments, while cooperating to design a new global financial system to avoid a crisis of this type in the future, take significant precautions in their homelands. Turkey also has to bear the severe consequences of this global trade and liquidity contraction beginning from the last quarter of 2008 .

The total corporate loans record their first contraction in June 2009. The CBRT makes the biggest policy rate cut in total between October 2008 and December 2009. This decision, to which banks react by increasing their lending rates first, motivates afterwards the short-term and longterm borrowing rates in the market to have a downward trend. When the data of borrowing rates for TL, USD and EURO is collected for the twenty three quarters and analyzed for the pre-crisis and crisis periods, the findings reveal that the interest rate difference between pre-crisis and crisis periods reaches 9\% approximately for TL loans and 2-3\% for USD loans. The interest rates for EURO loans succeed to return to pre-crisis levels in 2010 which are used to be between 4 and 5\%.

When the borrowing rates are analyzed based on the firm age, it is seen that from the shortterm perspective, young firms have to bear higher borrowing rates in both periods except for Euro credits in the crisis period. There is not much difference in the interest rate of long-term EURO credits for old and young firms in the pre-crisis period whereas in the crisis period old firms have to bear a higher rate compared to young firms as in the case of long-term TL credits in the crisis period.

Additionally, the results provide evidence that firms that are used to have higher cash savings in their hands in the pre-crisis period can obtain short and long-term credits with lower interest rates in the crisis period compared to low cash firms. The reason for this is that the banks 
feel more confident to give credits to firms that own high cash reserves on their balance sheets thinking of them as liquid collaterals.

Finally, it should be underlined that the speed of adjustment of market rates to policy rate reductions is very significant as Turkey succeeds to attenuate the severe effects of this global economic crisis with its policy rate cuts to avoid a credit crunch. 


\section{References}

ARSLAN, Özgür, FLORACKIS, Chrisostomos and OZKAN, Aydin (2006), “The Role of Cash Holdings in Reducing Investment -Cash Flow Sensitivity: Evidence from a Financial Crisis Period in an Emerging Market", University of York Discussion Papers Series in Economics, No.08.

Banking Regulation and Supervision Agency (March-June 2006). Financial Markets Report, No 1-2.

Banking Regulation and Supervision Agency (September 2006). Financial Markets Report, No3.

Banking Regulation and Supervision Agency (December 2006). Financial Markets Report, No4.

Banking Regulation and Supervision Agency (March 2007). Financial Markets Report, No5.

Banking Regulation and Supervision Agency (June 2007). Financial Markets Report, No6.

Banking Regulation and Supervision Agency (September 2007). Financial Markets Report, No7.

Banking Regulation and Supervision Agency (December 2007). Financial Markets Report, No8.

Banking Regulation and Supervision Agency (March 2008). Financial Markets Report, No9.

Banking Regulation and Supervision Agency (June 2008). Financial Markets Report, No10.

Banking Regulation and Supervision Agency (September 2008). Financial Markets Report, No11.

Banking Regulation and Supervision Agency (December 2008). Financial Markets Report, No12.

Banking Regulation and Supervision Agency (March 2009). Financial Markets Report, No13.

Banking Regulation and Supervision Agency (June 2009). Financial Markets Report, No14.

Banking Regulation and Supervision Agency (September 2009). Financial Markets Report, No15.

Banking Regulation and Supervision Agency (December 2009). Financial Markets Report, No16.

Banking Regulation and Supervision Agency (March 2010). Financial Markets Report, No17.

Banking Regulation and Supervision Agency (June 2010). Financial Markets Report, No18.

Banking Regulation and Supervision Agency (September 2010). Financial Markets Report, No19.

Banking Regulation and Supervision Agency (December 2010). Financial Markets Report, No20.

Banking Regulation and Supervision Agency (March 2011). Financial Markets Report, No21.

Banking Regulation and Supervision Agency (June 2011). Financial Markets Report, No22.

Banking Regulation and Supervision Agency (September 2011). Financial Markets Report, No23.

BAŞÇI, Erdem (2008), Conference of Global Financial Crisis and Monetary Policy, December, İstanbul.

BERNANKE, Ben, "Aftermath of the Crisis", College Lecture Series, Washington University, March 2012. http://www.federalreserve.gov/newsevents/lectures/the-aftermath-of-the-crisis.htm

CAMPELLO, Murillo, GIAMBONA, Erasmo, GRAHAM, John R. and HARVEY, Campbell R. (2010), "Liquidity management and corporate investment during a financial crisis”, NBER Working Paper Series, No.16309, August. 
CAMPELLO, Murillo, GRAHAM, John R. and HARVEY, Campbell R. (2009), "The real effects of financial constraints : evidence from a financial crisis", NBER Working Paper Series, No. 15552, December.

Central Bank of Turkish Republic (2008), Financial Stability Report No7. Ankara.

ÇAVUŞOĞLU, Fazilet (2010), "Para Politikası Faiz Oranlarından Mevduat ve Kredi Faiz Oranlarına Geçişkenlik: Türkiye Örneği”, Türkiye Cumhuriyeti Merkez Bankası, Uzmanlık Yeterlilik Tezi

DÖMBEKCI, Berna (2012), The Effects of 2008 Global Economic Crisis on Manufacturing Companies Listed at Istanbul Stock Exchange: Pre-crisis and Crisis Comparison, Marmara University Social Sciences Institute Phd Thesis, İstanbul.

DUCHIN, Ran, OZBAS, Oguzhan and SENSOY, Berk A. (2010), "Costly External Finance, Corporate Investment, and the Subprime Mortgage Credit Crisis," Journal of Financial Economics, Vol.97, pp.418-435.

GAMBACORTA, Leonardo (2004), “How Do Banks Set Interest Rates?”, NBER Working Paper No. 10295, February.

HANSEN, Niels-Jakob Harbo and WELZ, Peter (2011), "Interest Rate Pass-through During the Global Financial Crisis: The Case of Sweden”, OECD Economics Department Working Papers, No. 855, OECD Publishing.

IMF, World Economic Outlook April 2012, www.imf.org, (28.05.2013)

RAJAN, Raghuram and ZINGALES, Luigi (1998), "Financial Dependence and Growth”, American Economic Review, Vol. 88, pp.559-586.

SANTOS, Joao A. C. (2011),"Bank Corporate Loan Pricing Following the Subprime Crisis", Review of Financial Studies, Vol. 24, pp.1916-43.

TURHAN, M. İbrahim (2010), “Overview of the Turkish Economy and Monetary Policy Stance”, Deputy Governor of CBRT Presentations, January, London.

www.kap.gov.tr, Annual reports of Bourse Istanbul firms, (28.05.2013)

www.tcmb.gov.tr, Overnight rates, (28.05.2013) 
